\title{
Classical imaging findings of Dyke-Davidoff-Masson syndrome
}

\author{
Karan Manoj Anandpara, Yashant Aswani, Priya Hira
}

Seth G S Medical College and KEM Hospital, Mumbai, Maharashtra, India

\section{Correspondence to} Dr Yashant Aswani, aswaniyashant@gmail.com

Accepted 26 August 2014

\section{CrossMark}

To cite: Anandpara KM, Aswani Y, Hira P. BMJ Case Rep Published online: [please include Day Month Year] doi:10.1136/bcr-2014206682

\section{DESCRIPTION}

A 14-year-old girl, known case of seizure disorder since 10 years and mild mental retardation, presented with progressive left-sided hemiparesis and a recent increase in the frequency of seizures. Significant history included a developmental lag. A CT of the brain revealed marked cortical hemiatrophy on the right side with prominence of ipsilateral ventricular system (figure 1). Neuroparenchymal changes were accompanied with ipsilateral calvarial thickening and

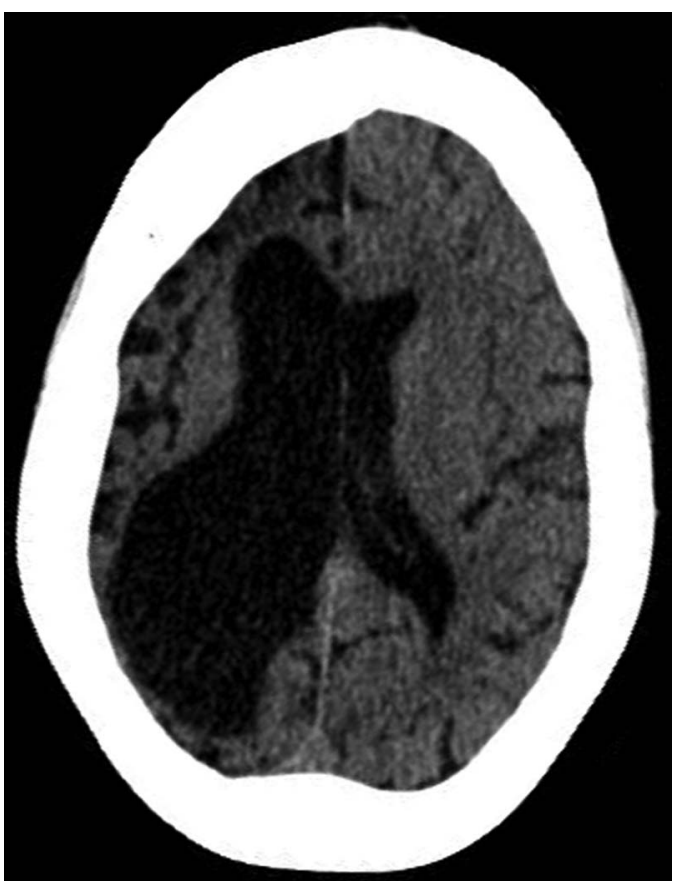

Figure 1 Axial section plain $\mathrm{CT}$ of the brain reveals marked right cerebral atrophy with right-sided ventricular dilation and widening of the ipsilateral sylvian fissure.
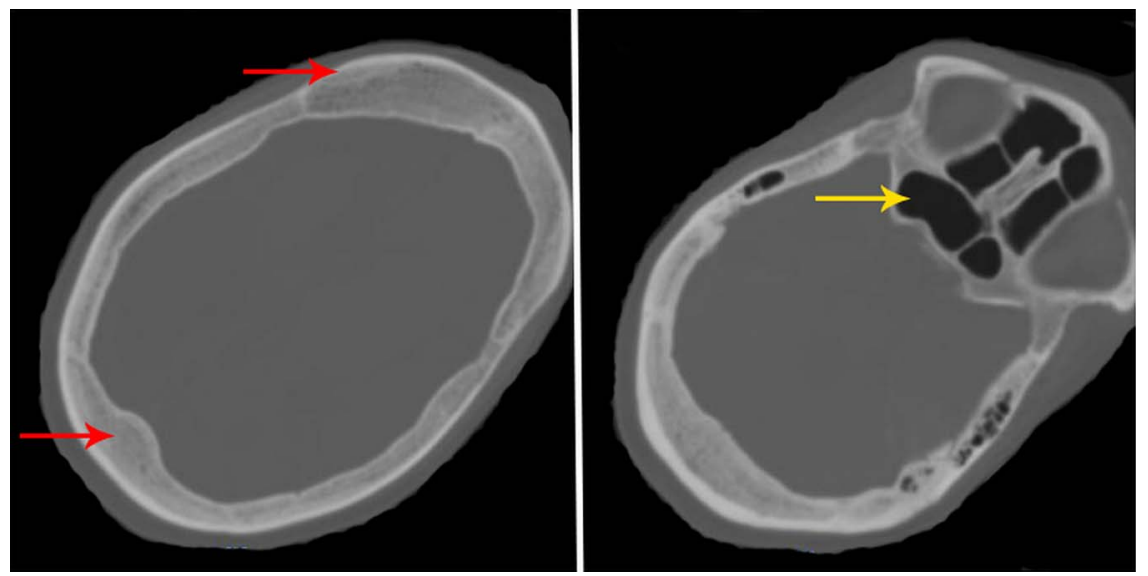

Figure 2 CT of the brain, bone window, reveals right-sided calvarial thickening (red arrows) and prominence of ipsilateral paranasal sinuses (yellow arrow). hyperpneumatisation of the paranasal sinuses on the right (figure 2). A diagnosis of Dyke-DavidoffMasson syndrome (DDMS) was thus established.

The pathophysiology of DDMS includes cortical hemiatrophy secondary to one-sided cerebral vascular insult, and may be congenital or acquired. ${ }^{12}$ The absence of sulcation in the former differentiates between the two. ${ }^{1}$ Compensatory widening of the diploic space and paranasal sinuses occurs as a consequence. Mimics of DDMS include Sturge-Weber syndrome (which shows the characteristic port wine stain, extensive pial enhancement and dystrophic calcification), ${ }^{2}$ Rasmusens encephalitis (in which calvarial changes are typically absent $)^{2}$ and unilateral complete occlusion of the middle cerebral artery (in which the hemiatrophy is in the territory of the middle cerebral artery vascular supply).

However, a combined clinical and radiological approach makes the diagnosis of DDMS straightforward. Neuroimaging in the form of CT or MRI is the gold standard and early detection is possible due to the classical findings.

\section{Learning points}

- Classical radiological imaging findings of the Dyke-Davidoff-Masson syndrome (DDMS) include cerebral hemiatrophy with compensatory ipsilateral calvarial thickening and hyperpneumatisation of the paranasal sinuses.

- CT or MRI is the gold standard, and the combination of clinical and imaging features solves the diagnostic dilemma.

- Subtle radiological signs can predict the timing of vascular insult and should be looked for while assessing a case of DDMS. 
Competing interests None.

\section{Patient consent Obtained.}

Provenance and peer review Not commissioned; externally peer reviewed.

\section{REFERENCES}

1 Shrestha B. Acquired cerebral hemiatrophy: Dyke-Davidoff-Masson syndrome-a case report. Turk Neurosurg 2013;23:117-21.

2 Behera MR, Patnaik S, Mohanty AK. Dyke-Davidoff-Masson syndrome. J Neurosci Rural Pract 2012;3:411-13.

Copyright 2014 BMJ Publishing Group. All rights reserved. For permission to reuse any of this content visit http://group.bmj.com/group/rights-licensing/permissions.

BMJ Case Report Fellows may re-use this article for personal use and teaching without any further permission.

Become a Fellow of BMJ Case Reports today and you can:

- Submit as many cases as you like

- Enjoy fast sympathetic peer review and rapid publication of accepted articles

- Access all the published articles

- Re-use any of the published material for personal use and teaching without further permission

For information on Institutional Fellowships contact consortiasales@bmjgroup.com

Visit casereports.bmj.com for more articles like this and to become a Fellow 